\title{
Enantioselective synthesis of 3-substituted dihydrobenzofurans through iridium-catalyzed intramolecular hydroarylation
}

Kana Sakamoto, Takahiro Nishimura

\begin{tabular}{|c|l|}
\hline Citation & Organic \& Biomolecular Chemistry. 19(3); 684-690. \\
\hline Issue Date & 2021-01-21 \\
\hline Type & Journal Article \\
\hline Textversion & author \\
\hline $\begin{array}{c}\text { Supplementary } \\
\text { files }\end{array}$ & Supplementary information is available at https://doi.org/10.1039/D0OB02421J. \\
\hline Relation & $\begin{array}{l}\text { The following article has been accepted by Organic \& Biomolecular Chemistry. } \\
\text { This is the accepted manuscript version. The final, published version is available } \\
\text { at https://doi.org/10.1039/D0OB02421J. }\end{array}$ \\
\hline DOI & $10.1039 / D 00 B 02421 \mathrm{~J}$ \\
\hline
\end{tabular}

\author{
Self-Archiving by Author(s) \\ Placed on: Osaka City University Repository
}

Sakamoto, K., \& Nishimura, T. (2021). Enantioselective synthesis of 3-substituted dihydrobenzofurans through iridium-catalyzed intramolecular hydroarylation. Organic \& Biomolecular Chemistry, 19(3), 684-690. https://doi.org/10.1039/d0ob02421j 


\title{
ARTICLE
}

\section{Enantioselective synthesis of 3-substituted dihydrobenzofurans through iridium-catalyzed intramolecular hydroarylation}

\begin{abstract}
Kana Sakamoto and Takahiro Nishimura*
Intramolecular hydroarylation via $\mathrm{C}-\mathrm{H}$ activation is one of the most powerful methods to synthesize carbo- and heterocyclic compounds, whereas we still have room for developing a highly enantioselective variant of the reaction. Here we describe Ir-catalyzed enantioselective intramolecular hydroarylation of $m$-allyloxyphenyl ketones. The enantioselective cyclization was efficiently catalyzed by a cationic iridium complex coordinated with a conventional chiral bisphosphine ligand to give benzofurans in high yields with high enantioselectivity. A carbonyl group of ketones functioned as an effective directing group for the $\mathrm{C}-\mathrm{H}$ activation. In terms of synthetic utility, we also achieved one-pot synthesis of chiral 3-substituted dihydrobenzofurans from readily available allylic carbonates and $m$-hydroxyacetophenones via sequential Pd-catalyzed allylic substitution and Ir-catalyzed intramolecular hydroarylation.
\end{abstract}

\section{Introduction}

Transition-metal-catalyzed intramolecular direct addition of aromatic $\mathrm{C}-\mathrm{H}$ bonds to unsaturated bonds, so-called hydroarylation, has provided efficient and facile routes to cyclic compounds with perfect atom-economy, ${ }^{1,2}$ and much attention has been paid to the asymmetric cyclization. Following a pioneering Rh-catalyzed direct intramolecular cyclization of 1,5or 1,6-dienes by Murai and co-workers, ${ }^{3}$ Bergman, Ellman, and co-workers reported intramolecular hydroarylation giving hetero- and carbocycles by chiral Rh catalysts (Scheme 1a). ${ }^{4}$ Substrates containing alkenyl tethers favored endo-cyclization to give five-membered rings in an enantioselective manner. Meanwhile, asymmetric exo-selective hydroarylation has been still underdeveloped (Scheme 1b). Cramer and co-workers developed enantioselective intramolecular hydroarylation to give exo products using a chiral $\mathrm{Rh} / \mathrm{Cp}$ complex. ${ }^{5}$ The reaction gives dihydrobenzofurans containing methyl-substituted quaternary stereocenters. Shibata and co-workers also reported asymmetric exo-cyclization of $\mathrm{N}$-alkenylindoles to give chiral 1-substituted-2,3-dehydro-1 $H$-pyrrolo[1,2-a]indoles. ${ }^{6 a}$ Moreover, Shibata found that enantioselective intramolecular formal $\mathrm{C}-\mathrm{H}$ conjugate addition of 4-methyl-1-aryl-2methylfumarates proceeded by a chiral Ir complex and gave chiral $\gamma$-lactones with a quaternary all-carbon stereogenic center.6b Cui and Wang independently reported Ru-catalyzed enantioselective intramolecular hydroarylation of benzaldehyde derivatives, which reacted with chiral amines to give imines functioning as chiral transient directing groups in situ. ${ }^{7}$ Cui successfully developed enantioselective cyclization

Department of Chemistry, Graduate School of Science, Osaka City University, Sumiyoshi, Osaka 558-8585, Japan E-mail: tnishi@sci.osaka-cu.ac.jp. Electronic Supplementary Information (ESI) available: Experimental procedures and compound characterization data. See DOI: 10.1039/x0xx00000x

for the synthesis of chiral indoline derivatives, while Wang reported 2,3-dihydrobenzofuran products bearing chiral all-

(a) Asymmetric intramolecular hydroarylation to give 5-endo-cyclization products

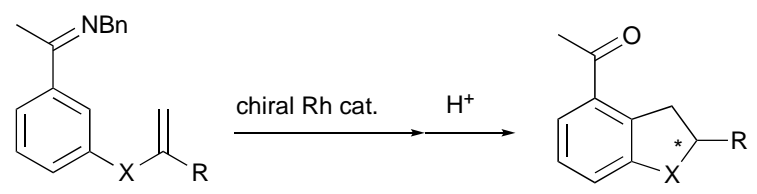

$\mathrm{X}=\mathrm{C}, \mathrm{O}$

(b) Asymmetric intramolecular hydroarylation to give 5-exo-cyclization products

$$
\text { Rh: Cramer (2014) }
$$

Ru: Cui (2019) and Wang (2020)<smiles>[X]C[C@]1([Z])C[X]c2cccc(C=O)c21</smiles>

(c) This work

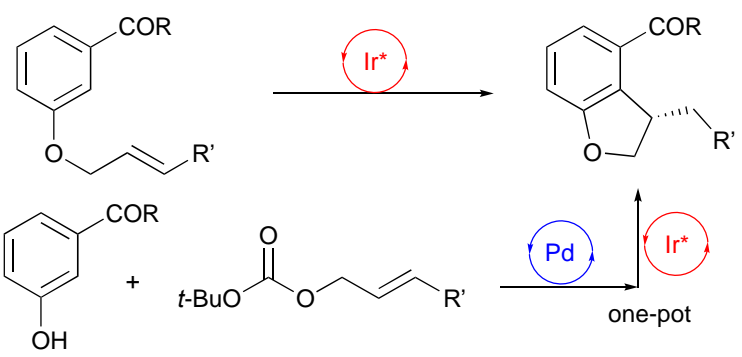

Scheme 1. Transition-metal-catalyzed asymmetric intramolecular hydroarylation<smiles>[R]C[C@@H]1CCn2c1c(C(=O)O[Na])c1ccccc12</smiles>

Ir: Cavallo and Rueping (2020)<smiles>O=C(O)c1cccc2c1[C@H](CBr)CO2</smiles> 
carbon quaternary stereocenters. Most recently, Cavallo and Rueping reported intramolecular hydroarylation of $\mathrm{m}$ cinnamyloxyphenyl ketones proceeded with high enantioselectivity in the presence of a cationic iridium catalyst. 8,9

We recently reported Ir-catalyzed intermolecular hydroarylation of $2 \mathrm{H}$-chromene with aromatic ketones. ${ }^{10,11}$ The reaction involves olefin isomerization of $2 \mathrm{H}$-chromene into $4 \mathrm{H}$ chromene, and then, chemo-, regio-, and enantioselective addition of aromatic $\mathrm{C}-\mathrm{H}$ bond to $4 \mathrm{H}$-chromene proceeds to give 2-arylchromanes with high enantioselectivity. We next focused on an intramolecular reaction via $\mathrm{C}-\mathrm{H}$ activation catalyzed by the Ir complex. Herein we report enantioselective intramolecular cyclization of $m$-allyloxyphenyl ketones catalyzed by a cationic iridium/chiral bisphosphine catalyst (Scheme 1c). Chiral dihydrobenzofurans, which are important scaffolds in natural products and bioactive compounds, ${ }^{12}$ are provided by the reaction in a highly enantioselective manner. Moreover, we successfully synthesized dihydrobenzofurans from readily available allylic carbonates and $m$ hydroxyacetophenones via formal intermolecular annulation by combining Ir-catalyzed intramolecular hydroarylation with Pdcatalyzed allylic substitution.

\section{Results and discussion}

To begin our study of intramolecular hydroarylation, we conducted the reaction of $m$-allyloxybenzophenone (1a) by using a cationic iridium complex (Scheme 2a). Treatment of 1a in the presence of $[\mathrm{IrCl}(\operatorname{cod})]_{2}(5 \mathrm{~mol} \%$ of $\mathrm{Ir}, \operatorname{cod}=1,5-$ cyclooctadiene), (rac)-binap (6 mol\%), and $\mathrm{NaBAr}_{4}$ [10 mol\%, $\left.\operatorname{Ar}^{\mathrm{F}}=3,5-\left(\mathrm{CF}_{3}\right)_{2} \mathrm{C}_{6} \mathrm{H}_{3}\right]$, which are typical reagents for the catalytic hydroarylation, ${ }^{10}$ in toluene at $80{ }^{\circ} \mathrm{C}$ for $13 \mathrm{~h}$ gave dihydrobenzofuran $\mathbf{2 a}$ in $55 \%$ yield accompanied by the formation of vinyl ether $\mathbf{3 a}$. The selective 5-exo-cyclization occurred to give $2 \mathrm{a}$ and the 6-endo-cyclized product was not observed at all. Unfortunately, however, neither increase of amount of the catalyst or longer reaction time had no effect on the yields or selectivity of the products at that stage. In contrast, when cinnamyloxy ether 1b, which has an internal alkene moiety, was treated under the same reaction conditions, the corresponding cyclized product $\mathbf{2} \mathbf{b}$ was obtained in $71 \%$ yield<smiles>C=CCOc1cccc(C(C)=O)c1</smiles>

1a



2a: $55 \%$

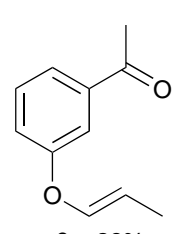

3a: $28 \%$ (b)

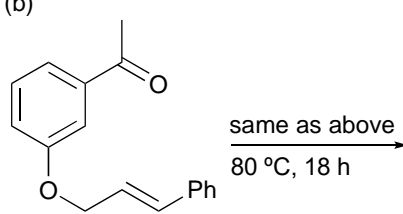

$1 \mathrm{~b}$

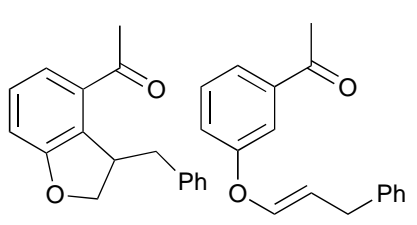

2b: $71 \%$

3b: $0 \%$ without formation of the isomerized product $\mathbf{3 b}$ (Scheme $2 b$ ). The results prompted us to develop asymmetric variant of the reaction of $\mathbf{1 b}$ as a model substrate.

The enantioselectivity obtained with conventional chiral bisphosphine ligands in the Ir-catalyzed 5-exo-cyclization of $\mathbf{1 b}$ are shown in Table 1 . The use of $(R)$-binap ${ }^{13}$ gave $\mathbf{2 b}$ in $67 \%$ yield with $64 \%$ ee (entry 1 ). Segphos ${ }^{14}$ and difluorphos ${ }^{15}$ both improved the reactivity and enantioselectivity, giving $\mathbf{2 b}$ in 88 and $92 \%$ yields with 73 and $84 \%$ ee, respectively (entries 2 and $3)$. The reaction using $(R)$-MeO-biphep ${ }^{16}$ resulted in the formation of a trace amount of $\mathbf{2} \mathbf{b}$ (entry 4$)$. $(S, S)$-Chiraphos ${ }^{17}$ also worked as a ligand to give $\mathbf{2} \mathbf{b}$ in a moderate yield with modest enantioselectivity (entry 5). After testing several other ligands, we found that $(S, S)$-Quinox $P^{* 18}$ displayed excellent enantioselectivity ( $97 \%$ ee, entry 6$)$, albeit with the modest yield. An elevated temperature of $100{ }^{\circ} \mathrm{C}$ improved the yield of 2b up to $85 \%$ without compromising the enantioselectivity (entry 7).

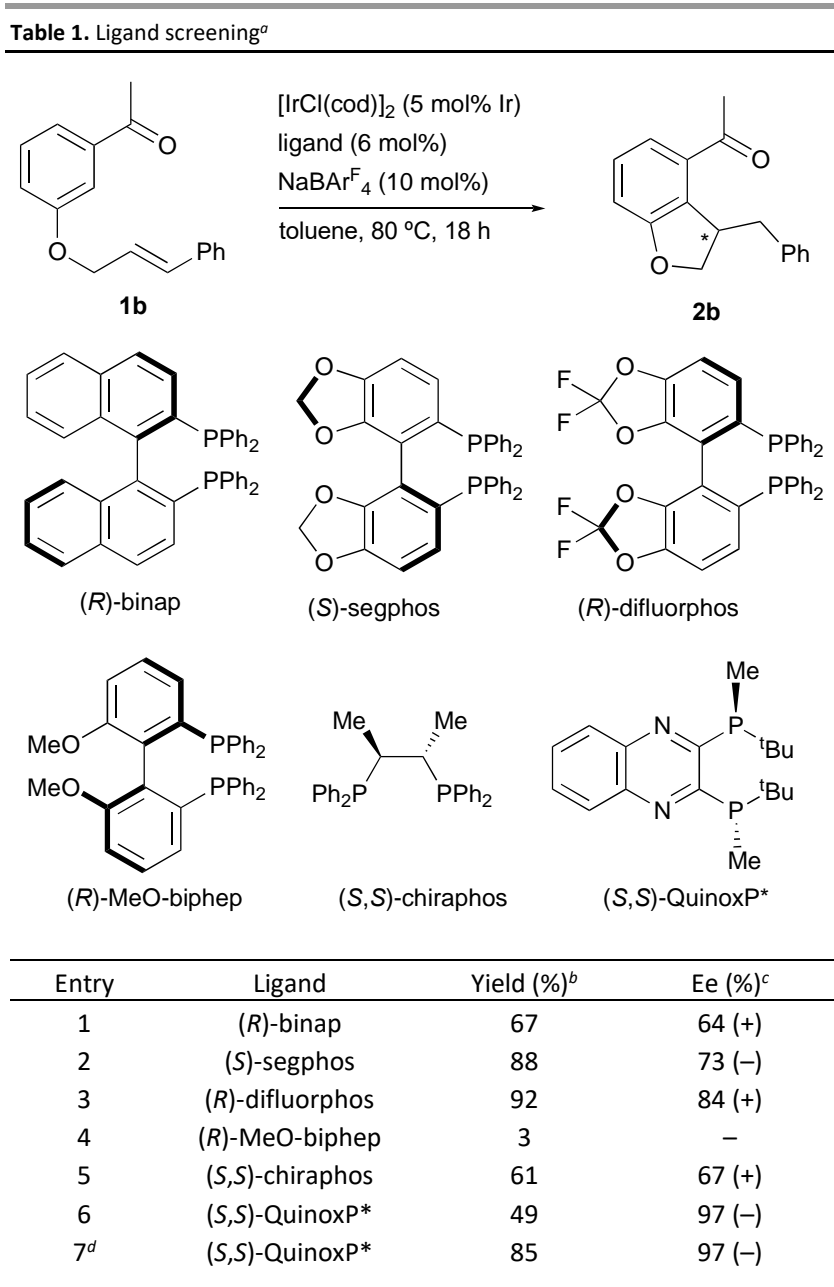

${ }^{a}$ Reaction conditions: $1 \mathbf{b}(0.10 \mathrm{mmol}),[\mathrm{IrCl}(\operatorname{cod})]_{2}(5 \mathrm{~mol} \%$ of $\mathrm{Ir}),(S, S)$-QuinoxP* (6 mol\%), and $\mathrm{NaBAr}_{4}(10 \mathrm{~mol} \%)$ in toluene $(0.2 \mathrm{~mL})$ at $80{ }^{\circ} \mathrm{C}$ for $18 \mathrm{~h}$. ${ }^{b}$ Determined by ${ }^{1} \mathrm{H}$ NMR analysis using benzyl phenyl ether as an internal standard. 'Determined by HPLC analysis with a chiral stationary phase column: Chiralcel OJ-H. ${ }^{d}$ At $100{ }^{\circ} \mathrm{C}$. 
Scheme 3 summarizes the results obtained for the enantioselective hydroarylation of m-cinnamyloxyphenyl ketones using $(S, S)$-QuinoxP* or $(S)$-difluorphos as a ligand. The intramolecular hydroarylation of benzophenones substituted with both electron-donating and -withdrawing groups all<smiles>[Y]C=CCOc1cccc(C([X])=O)c1</smiles>

1

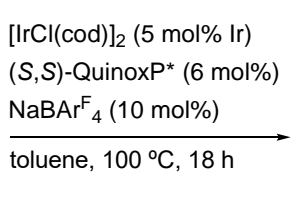

$(S, S)$-QuinoxP* $(6 \mathrm{~mol} \%)$ $\mathrm{NaBAr}_{4}(10 \mathrm{~mol} \%)$

toluene, $100^{\circ} \mathrm{C}, 18 \mathrm{~h}$

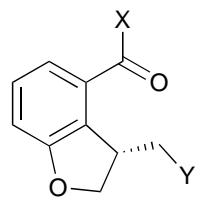

2<smiles>O=C(c1ccccc1)c1cccc2c1[C@H](Cc1ccccc1)CO2</smiles>

$\mathrm{H}(2 \mathrm{c}) \quad 67 \%, 96 \%$ ee $4-\mathrm{NMe}_{2}$ (2d) $\quad 80 \%, 86 \%$ ee $4-\mathrm{MeO}(2 \mathrm{e}) \quad>99 \%, 82 \% \mathrm{ee}^{b}$ $4-\mathrm{CF}_{3}(\mathbf{2 f}) \quad 82 \%, 98 \% \mathrm{ee}^{\mathrm{c}}$ $3-\mathrm{MeO}(\mathbf{2 g}) \quad 77 \%, 96 \%$ ee $3,5-\mathrm{Me}_{2}(\mathbf{2 h}) \quad 94 \%, 96 \%$ ee

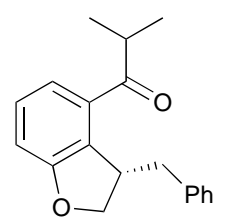

2i: $90 \%, 90 \% \mathrm{ee}^{b}$<smiles>CCCCC(=O)c1cccc2c1[C@@H](Cc1ccccc1)CO2</smiles><smiles>COc1cc2c(c(C(C)=O)c1)[C@H](Cc1ccccc1)CO2</smiles><smiles>O=C1CCCc2ccc3c(c21)[C@H](Cc1ccccc1)CO3</smiles>

2j: $84 \%, 96 \% \mathrm{ee}^{c}$<smiles>CCOC(=O)c1cccc2c1[C@H](Cc1ccccc1)CO2</smiles>

2m: $0 \%$<smiles>CC(=O)O[R6](=O)(O[Na])O[Na]</smiles>

2n: $0 \%$ 2l: $95 \%, 98 \%$ ee<smiles>CC(=O)c1cccc2c1[C@@H](Cc1ccc(C)cc1)CO2</smiles>
2o: $63 \%, 85 \%$ ee<smiles>[R]c1ccc(C[C@@H]2COc3cccc(C(C)=O)c32)cc1</smiles>

$R=\operatorname{Me}(\mathbf{2 p}) \quad 89 \%, 98 \%$ ee $\mathrm{Cl}(2 \mathbf{q}) \quad 89 \%, 94 \%$ ee $\mathrm{CF}_{3}(2 \mathrm{r}) \quad 67 \%, 89 \%$ ee<smiles>COc1ccccc1C[C@@H]1COc2cccc(C(C)=O)c21</smiles>

2s: $80 \%, 97 \%$ ee $\quad 2 t: 81 \%, 93 \%$ ee ${ }^{d}$<smiles>CC(=O)c1cccc2c1[C@H](Cc1ccco1)CO2</smiles><smiles>CCCCCC[C@H]1COc2cccc(C(C)=O)c21</smiles>

2v: $73 \%, 56 \%$ ee

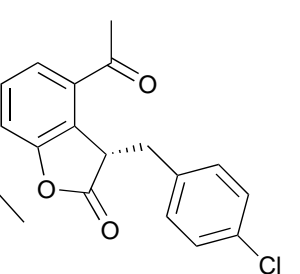

2w: $0 \%$

${ }^{a}$ Reaction conditions: 1 (0.10 mmol), [ $[\mathrm{rCl}(\operatorname{cod})]_{2}$ (5 mol\% of $\left.\mathrm{Ir}\right),(S, S)$-QuinoxP* $(6 \mathrm{~mol} \%)$ and $\mathrm{NaBAr}_{4}(10 \mathrm{~mol} \%)$ in toluene $(0.2 \mathrm{~mL})$ at $100^{\circ} \mathrm{C}$ for $18 \mathrm{~h}$. Isolated yields are shown. ${ }^{b}(S)$-Difluorphos was used instead of $(S, S)$-QuinoxP*. ${ }^{c} 10 \mathrm{~mol} \%$ of $\mathrm{Ir}, 12 \mathrm{~mol} \%(S, S)$ QuinoxP*, and 20 mol\% of $\mathrm{NaBAr}_{4}$ were used. ${ }^{d}(R)$-Difluorphos was used.

Scheme 3. Ir-catalyzed intramolecular hydroarylation of m-cinnamyloxyphenyl ketones $^{a}$

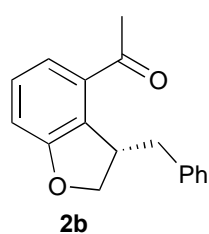

$\mathbf{2 b}$

$97 \%$ ee

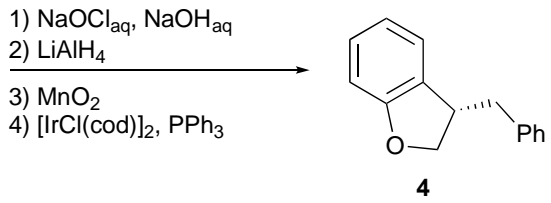

$65 \%$ (4 steps), $97 \%$ ee $[\alpha]^{25} \mathrm{D}+37.4$ (c $\left.=0.37, \mathrm{CHCl}_{3}\right)(\mathrm{S})$
Scheme 4. Determination of the absolute configuration

proceeded smoothly to give cyclized products in good to high yields with high enantioselectivity (2c-h). Besides benzophenone derivatives, isopropyl ketone $\mathbf{1 i}$ and butyl ketone $\mathbf{1 j}$ were suitable for the reaction and gave cyclic products with high enantioselectivity. The reactions of $\mathrm{m}$ substituted acetophenone $\mathbf{1 k}$ and $\alpha$-tetralone derivative $\mathbf{1}$ also took place to give the corresponding products with high enantioselectivity. In contrast, an ester group in $\mathbf{1} \mathbf{m}$ did not work as a directing group. The reaction of allylic amide $\mathbf{1 n}$ either gave no cyclized product $\mathbf{2 n}$. The present catalytic system can also be applied to several acetophenones bearing substituted cinnamyloxy groups. Substituents at para-, meta-, and orthopositions of the cinnamyl groups hardly affected the reactivity and enantioselectivity, thus giving the corresponding cyclized products 20-t in high yields with high enantioselectivity. Aromatic ketones having a 2-furyl group (1u) and an alkyl group (1v) instead of the aryl groups also underwent intramolecular hydroarylation to give $\mathbf{2 u}$ and $\mathbf{2 v}$ with $85 \%$ and $56 \%$ ee, respectively, while $\alpha, \beta$-unsaturated ester $\mathbf{1} \mathbf{w}$ was inert under the present catalytic conditions.

To determine the absolute configuration of the cyclization products $\mathbf{2}$, dihydrobenzofuran $\mathbf{2} \mathbf{b}$ obtained by the present reaction, was converted into a known compound (Scheme 4). Haloform reaction of $\mathbf{2} \mathbf{b}$ with $\mathrm{NaOCl}$ solution gave the corresponding carboxylic acid after acidic work-up. The carboxyl group was transformed into an aldehyde, and then, Ircatalyzed deformylation of the aldehyde gave dihydrobenzofuran 4 . The absolute configuration of 4 was determined to be $S-(+)$ by comparison of its specific rotation with the value reported previously: $4[\alpha]^{25}{ }_{D}+37.4(c=0.37$, $\mathrm{CHCl}_{3}$ ) for $97 \%$ ee; lit. ${ }^{19}[\alpha]^{20}{ }_{D}+41.3\left(c=0.75, \mathrm{CHCl}_{3}\right)$ for $86 \%$ ee (S)-4.

As shown in Scheme 5, it was found by chance that a presence of 4-methoxystyrene (5a) significantly improved the yield of the cyclized product in a shorter reaction time without participating in the reaction. Thus, the yield of $\mathbf{2} \mathbf{b}$ was $29 \%$ after $1.5 \mathrm{~h}$ of the reaction of $\mathbf{1} \mathbf{b}$ under the standard reaction conditions, whereas the reaction in the presence of 4methoxystyrene (5a, 50 mol\%) gave $\mathbf{2 b}$ in $84 \%$ yield with $98 \%$ ee. Styrene (5b) also displayed an enhancement of the reactivity, thus giving $\mathbf{2 b}$ in $46 \%$. In contrast, 4 -chlorostyrene (5c) did not influence the reaction. The asymmetric cyclization of $\mathbf{1 b}$ in the presence of deuterated 4-methoxystyrene $\left(\mathbf{5 a}-\boldsymbol{d}_{\mathbf{3}}\right)^{20}$ smoothly proceeded to give $\mathbf{2} \mathbf{b}$ in $97 \%$ yield after $3 \mathrm{~h}$, where a 
deuterium incorporation into $\mathbf{2} \mathbf{b}$ was not observed (Scheme $5 b$ ). The result implies that a hydridoiridium species formed by ortho- $\mathrm{C}-\mathrm{H}$ activation may not react with $\mathbf{5 a}-\boldsymbol{d}_{\mathbf{3}}$ intermolecularly. ${ }^{21}$ A positive effect of 4-methoxystyrene (5a) was also observed in the cyclization of 1a. Thus, the reaction of $\mathbf{1 a}$ in the presence of $\mathbf{5 a}$ using $(S, S)$-chiraphos gave cyclized product $2 \mathrm{a}$ in $62 \%$ yield with $77 \%$ ee accompanied by formation of $18 \%$ of isomerized product $\mathbf{3 a}$, indicating that the presence of $5 a$ slightly suppressed the olefin isomerization. The use of $(S, S)$-QuinoxP* resulted in a low enantioselectivity ( $25 \%$ ee), although the formation of $3 a$ was well inhibited. At present, the role of 4-methoxystyrene to improve the yield is not yet clear, and the possibility of the contribution as a secondary ligand of the iridium species cannot be excluded.

The results of deuterium-labeling experiments are shown in Scheme 6. Treatment of $\mathbf{1 l}-\boldsymbol{d}$ under the standard reaction conditions gave $\mathbf{2 l}-\boldsymbol{d}$ in $45 \%$ yield. The obtained product $\mathbf{2 l}-\boldsymbol{d}$ contained deuterium at the benzylic position of the phenyl group as expected, and $H / D$ exchange $(8 \% D)$ at the $C-3$ position of the dihydrobenzofuran ring was also observed, indicating that the reaction is accompanied by ortho- $\mathrm{C}-\mathrm{H}$ activation and subsequent reversible hydrometalation and $\beta$-hydrogen elimination. Intermolecular KIE (kinetic isotope effect) 22 was observed in the competitive reaction of a 1:1 mixture of $\mathbf{1 l}$ and

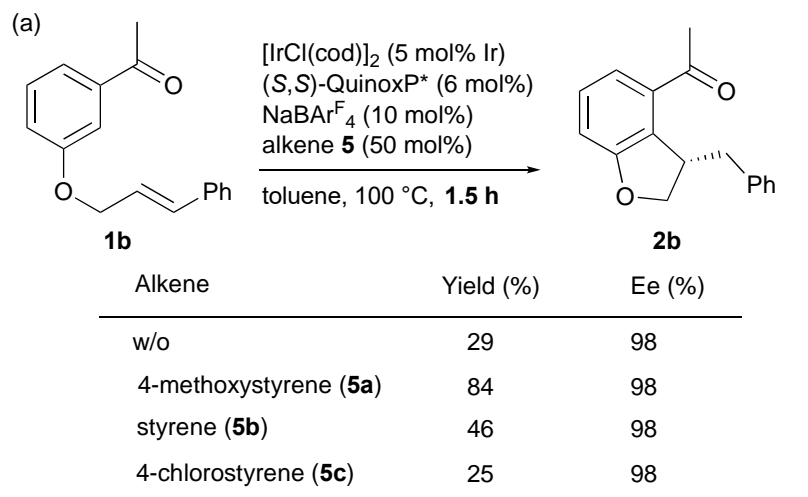

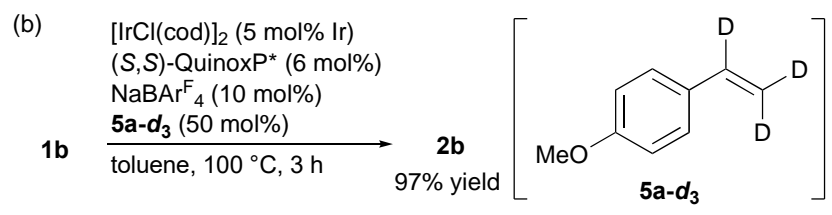

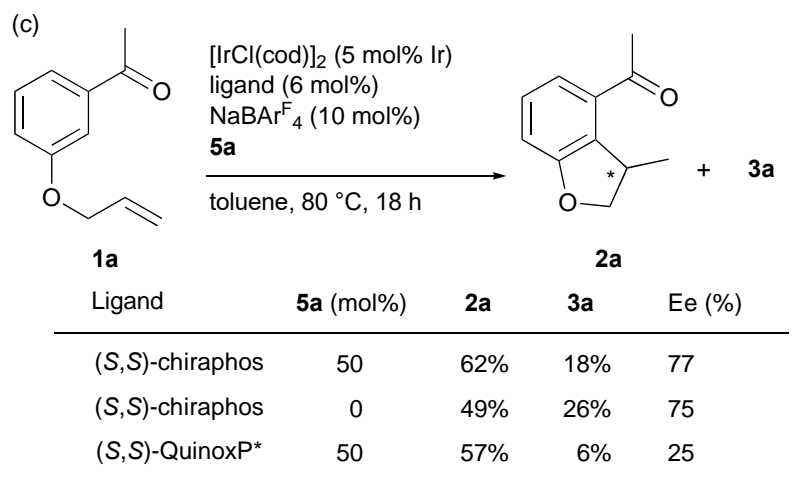

Scheme 5. Effect of 4-methoxystyrene $\mathbf{1} \mathbf{l} \boldsymbol{d}(\mathrm{KIE}=1.5)$. In parallel cyclization reactions of $\mathbf{1}$ and $\mathbf{1} \mathbf{I}-\boldsymbol{d}$, the difference of the reactivity was also observed $(\mathbf{2 l} / \mathbf{2 l}-\boldsymbol{d}=1.5)$.<smiles>O=C1CCCc2ccc(OC/C=C/c3ccccc3)c(O)c21</smiles>

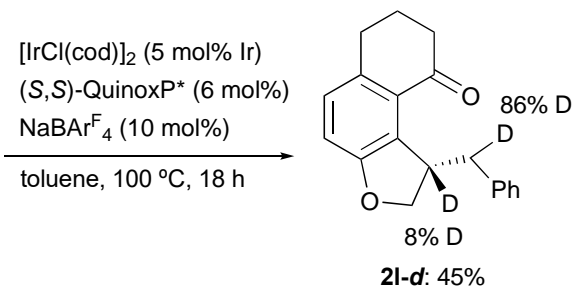

(b)

$$
\begin{gathered}
11 \\
(0.05 \mathrm{mmol}) \\
+ \\
11-d \\
(0.05 \mathrm{mmol})
\end{gathered}
$$

$[\mathrm{IrCl}(\operatorname{cod})]_{2}(5 \mathrm{~mol} \% \mathrm{Ir})$

$(S, S)$-QuinoxP* $(6$ mol\%) $\mathrm{NaBAr}_{4}(10 \mathrm{~mol} \%)$ toluene, $100^{\circ} \mathrm{C}, 1 \mathrm{~h}$<smiles>O=C1CCCc2ccc3c(c21)[C@H](C(c1ccccc1)c1ccccc1)CO3</smiles>

(c)

$$
[\mathrm{IrCl}(\mathrm{cod})]_{2}(5 \mathrm{~mol} \% \mathrm{Ir})
$$

2l-d: $18 \%$ $(S, S)$-QuinoxP* $(6 \mathrm{~mol} \%)$
11 $\mathrm{NaBAr}_{4}(10 \mathrm{~mol} \%)$
11-d
21: $31 \%$
21-d: $20 \%(80 \%$ D)<smiles>CC(=O)c1cccc2c1C(Cc1ccccc1)CO2</smiles>

Scheme 7. Proposed catalytic cycle

A plausible catalytic cycle of the present reaction is postulated as illustrated in Scheme 7. Oxidative addition of ortho- $\mathrm{C}-\mathrm{H}$ bond to a cationic iridium $\mathbf{A}$ generates an aryl(hydrido)iridium(III) species B. Species B undergoes irreversible carbometalation to form intermediate $\mathbf{C}$, and sequential formation of a $\mathrm{C}-\mathrm{H}$ bond by reductive elimination gives cyclized product $\mathbf{2} \mathbf{b}$ and regenerates species $\mathbf{A}$. Species $\mathbf{B}$ 
might also give intermediates $\mathbf{E}$ and $\mathbf{F}$ through reversible hydrometalation. Based on computational studies on Ircatalyzed hydroarylation, the carbometalation might be a turnover limiting step of the present reaction, ${ }^{23,8}$ although we observed KIE of $\mathrm{C}-\mathrm{H}$ activation. ${ }^{22}$

Table 2. Pd-catalyzed allylic substitution of allyl carbonate $\mathbf{6}^{\circ}$<smiles>CC(=O)c1cccc(OC(=O)OC/C=C/c2ccccc2)c1</smiles>

Pd complex $(5 \mathrm{~mol} \%$ of $\mathrm{Pd})$ ligand $(6 \mathrm{~mol} \%)$ toluene, $40^{\circ} \mathrm{C}, 3 \mathrm{~h}$

6<smiles>C1=Cc2ccccc2N(P2Oc3ccccc3-c3ccccc32)c2ccccc21</smiles>

L1

\begin{tabular}{cccc}
\hline Entry & $\mathrm{Pd} \mathrm{Complex}$ & Ligand & ${\text { Yield }(\%)^{b}}^{b}$ \\
\hline 1 & $\mathrm{Pd}_{2}(\mathrm{dba})_{3} \cdot \mathrm{CHCl}_{3}$ & none & 25 \\
2 & $\mathrm{Pd}_{2}(\mathrm{dba})_{3} \cdot \mathrm{CHCl}_{3}$ & $($ rac $)$-binap & 43 \\
3 & $\mathrm{Pd}_{2}(\mathrm{dba})_{3} \cdot \mathrm{CHCl}_{3}$ & $\mathrm{dppf}$ & 81 \\
4 & $\mathrm{Pd}_{2}(\mathrm{dba})_{3} \cdot \mathrm{CHCl}_{3}$ & L1 & 86 \\
5 & $\mathrm{Pd}(\mathrm{OAc})_{2}$ & L1 & 32
\end{tabular}

${ }^{a}$ Reaction conditions: 6 ( $0.10 \mathrm{mmol}$ ), Pd complex ( $5 \mathrm{~mol} \%$ of $\mathrm{Pd}$ ), and ligand (6 mol\%) in toluene $(0.2 \mathrm{~mL})$ at $40{ }^{\circ} \mathrm{C}$ for $3 \mathrm{~h}$. ${ }^{b}$ Determined by ${ }^{1} \mathrm{H} N M R$ analysis using benzyl phenyl ether as an internal standard.

(a)

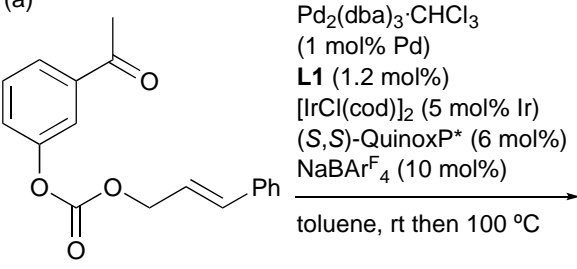

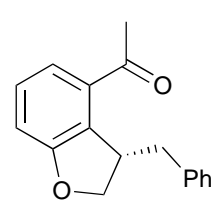

2b: $0 \%$ (b)

$$
\begin{aligned}
& \mathrm{Pd}_{2}(\mathrm{dba})_{3} \cdot \mathrm{CHCl}_{3} \\
& \text { (1 mol\% Pd) } \\
& \text { L1 }(1.2 \mathrm{~mol} \%) \\
& {[\mathrm{IrCl}(\mathrm{cod})]_{2}(5 \mathrm{~mol} \% \mathrm{Ir})} \\
& 6 \underset{\text { toluene, rt, } 30 \mathrm{~min}}{\stackrel{(S, S) \text {-QuinoxP* }}{\stackrel{(6 \mathrm{~mol} \%)}{\longrightarrow}}} \frac{\mathrm{NaBAr}_{4}(10 \mathrm{~mol} \%)}{100^{\circ} \mathrm{C}, 14 \mathrm{~h}} \mathbf{2 b : 0 \%}
\end{aligned}
$$

(c) $\mathrm{Pd}_{2}(\mathrm{dba})_{3} \cdot \mathrm{CHCl}_{3} \quad[\mathrm{IrCl}(\mathrm{cod})]_{2}(5 \mathrm{~mol} \% \mathrm{Ir})$ L1 (1.2 mol\%) $\quad \mathrm{NaBAr}_{4}(10 \mathrm{~mol} \%)$

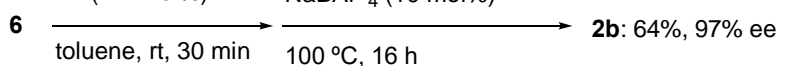

Scheme 8. Pd-catalyzed allylic substitution and Ir-catalyzed asymmetric intramolecular hydroarylation

m-Cinnamyloxyphenyl ketones $\mathbf{1}$, which underwent Ircatalyzed asymmetric hydroarylation, can be prepared by $\mathrm{Pd}$ catalyzed allylic substitution of allylic compounds, such as allylic $(1 \mathrm{~mol} \% \mathrm{Pd}) \quad(S, S)$-QuinoxP* $(6 \mathrm{~mol} \%)$ carbonates and esters with phenol derivatives. ${ }^{24}$ In this respect, we next focused on the synthesis of chiral dihydrobenzofurans by formal intermolecular annulation of phenol derivatives with allylic compounds through Pd-catalyzed allylic substitution and Ir-catalyzed intramolecular hydroarylation. In the first set of experiments, intramolecular allylic substitution was examined by use of a readily available allyl carbonate 6 to find out an efficient $\mathrm{Pd}$ catalyst giving the corresponding allyl ether $\mathbf{1 b}$ (Table 2). Treatment of 6 with $\mathrm{Pd}_{2}(\mathrm{dba})_{3} \cdot \mathrm{CHCl}_{3} \quad(\mathrm{dba}=$ dibenzylideneacetone) in toluene at $40{ }^{\circ} \mathrm{C}$ for $3 \mathrm{~h}$ gave ether $\mathbf{1 b}$ in $25 \%$ yield (entry 1 ). The reaction of 6 in the presence of binap gave $\mathbf{1 b}$ in $43 \%$ yield (entry 2). Dppf [1,1'bis(diphenylphosphino)ferrocene] and ligand $\mathbf{L} \mathbf{1}^{25}$ were found to efficiently promote the allylic substitution, giving $\mathbf{1 b}$ in $81 \%$ and $86 \%$ yields, respectively (entries 3 and 4$). \mathrm{Pd}_{2}(\mathrm{dba})_{3} \cdot \mathrm{CHCl}_{3}$ was a better catalyst precursor than $\mathrm{Pd}(\mathrm{OAc})_{2}$ with L1 (entries 4 and 5). ${ }^{26}$

We next tried to synthesize dihydrobenzofurans via intramolecular allylic substitution of $\mathbf{6}$ and intramolecular hydroarylation in a single operation. Thus, allyl carbonate 6 was added to a solution of premixed $\mathrm{Pd}_{2}(\mathrm{dba})_{3} \cdot \mathrm{CHCl}_{3}(1 \mathrm{~mol} \%$ of $\mathrm{Pd})$ and $\mathbf{L 1}(1.2 \mathrm{~mol} \%)$, and premixed $[\mathrm{IrCl}(\operatorname{cod})]_{2}(5 \mathrm{~mol} \%$ of Ir), $(S, S)$ QuinoxP* (6 mol\%), and $\mathrm{NaBAr}_{4}(10 \mathrm{~mol} \%)$ in toluene, and the resulting mixture was stirred at room temperature for $30 \mathrm{~min}$ and heated to $100{ }^{\circ} \mathrm{C}$ (Scheme 8a). The reaction resulted in recovery of the starting material, and several control experiments revealed that $\mathrm{NaBAr}_{4}$ inhibited the allylic substitution. Therefore, after completion of the allylic substitution in the presence of the Pd and Ir catalysts without $\mathrm{NaBAr}_{4}$, which was monitored by TLC, NaBArF${ }_{4}$ was added to the reaction mixture (Scheme $8 \mathrm{~b}$ ). Unfortunately, however, after the mixture was heating at $100^{\circ} \mathrm{C}$ for $14 \mathrm{~h}$, the formation of the cyclized product was not observed. Following the results, of the first stage of the sequential reactions. Treatment of 6 in the presence of $\mathrm{Pd}_{2}(\mathrm{dba})_{3} \cdot \mathrm{CHCl}_{3}$ and $\mathbf{L 1}$ in toluene at room temperature for $30 \mathrm{~min}$, followed by the successive addition of $[\mathrm{IrCl}(\mathrm{cod})]_{2},(S, S)$-QuinoxP* (6 mol\%), and $\mathrm{NaBAr}_{4}$ to the reaction mixture, gave cyclized product $\mathbf{2 b}$ in $64 \%$ yield with $97 \%$ ee after heating at $100{ }^{\circ} \mathrm{C}$ for $16 \mathrm{~h}$ (Scheme $8 \mathrm{c}$ ).

The present one-pot reaction system can be applied to intermolecular reaction achieving formal intermolecular annulation between $m$-hydroxyacetophenone and allyl carbonate (Scheme 9). Thus, treatment of $m$ -<smiles>CC(=O)c1cccc(O)c1</smiles>
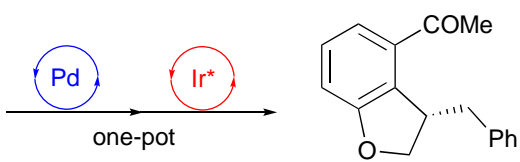
we next focused on the one-pot protocol without any work-up

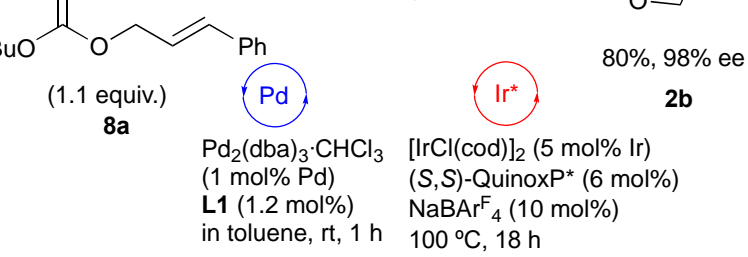

Scheme 9. One-pot synthesis of dihydrobenzofuran by dual catalysis 
hydroxyacetophenone (7a) with 1.1 equiv. of tert-butyl cinnamyl carbonate (8a) in the presence of the Pd catalyst in toluene at room temperature for $1 \mathrm{~h}$, and then sequential addition of the iridium catalyst gave, after heating, dihydrobenzofuran $\mathbf{2 b}$ in $80 \%$ yield, whose ee was $98 \%$.

As shown in Scheme 10, benzophenones with electrondonating and -withdrawing groups were all good substrates for the formal intermolecular annulation by two catalytic systems to give dihydrobenzofuran $\mathbf{2 c - f}$ in high yields with high enantioselectivity. In addition to benzophenones, butyl ketone also participated in the reaction to give $\mathbf{2 j}$ with $98 \%$ ee. $\mathrm{m}$ Hydroxyacetophenones substituted with methoxy and bromo groups at the aromatic rings also reacted with the carbonate $\mathbf{8 a}$ smoothly to give dihydrobenzofurans (2k, 2x, and $2 \mathbf{2 y}$ ). Substituted cinnamyl carbonates and an allylic carbonate having a 2-furyl group can also be applied to the reaction with $m$-hydroxyacetophenone (7a) to give dihydrobenzofurans $\mathbf{2 0}$, $\mathbf{2 q}, \mathbf{2 t}$, and $\mathbf{2} \mathbf{u}$ in high yields with high enantioselectivity.<smiles>[X]C(=O)c1cccc(O)c1</smiles><smiles>[Y]C=CCOC(=O)OC(C)(C)C</smiles>
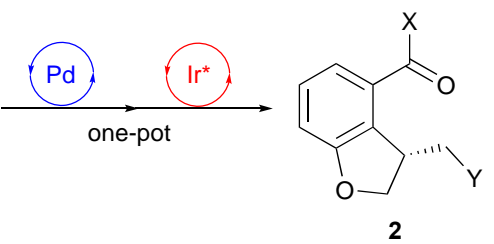<smiles>[X]c1ccc(C(=O)c2cccc3c2[C@@H](Cc2ccccc2)CO3)cc1</smiles><smiles>CC(=O)c1cc(Br)cc2c1[C@H](Cc1ccccc1)CO2</smiles>

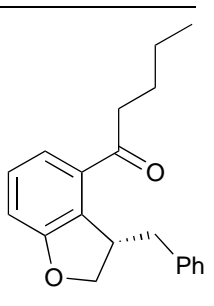

2j: $87 \%, 98 \%$ ee

2k: $70 \%, 97 \% \mathrm{ee}^{b}$ 2x: $99 \%, 83 \% \mathrm{ee}^{c, d}$<smiles>[X]c1ccc(C[C@@H]2COc3cccc(C(C)=O)c32)cc1</smiles><smiles>COc1ccccc1C[C@@H]1COc2cccc(C(C)=O)c21</smiles><smiles>CC(=O)c1cccc2c1[C@@H](Cc1ccco1)CO2</smiles>

2u: $72 \%, 88 \% \mathrm{ee}^{c}$

2o $(\mathrm{X}=\mathrm{MeO}): 84 \%, 87 \%$ ee $\mathrm{e}^{c, d} \quad \mathbf{2 t}: \mathbf{8 0} \%, 94 \% \mathrm{ee}^{c}$ $2 q(X=C l): 81 \%, 94 \%$ ee ${ }^{d}$

${ }^{a}$ Reaction conditions: 7 ( $\left.0.10 \mathrm{mmol}\right), 8$ (1.1 equiv.), $\mathrm{Pd}_{2}(\mathrm{dba})_{3} \cdot \mathrm{CHCl}_{3}(1 \mathrm{~mol} \%$ of $\mathrm{Pd})$, and L1 $(1.2 \mathrm{~mol} \%)$ in toluene $(0.2 \mathrm{~mL})$ at $40{ }^{\circ} \mathrm{C}$ for $1 \mathrm{~h}$ and sequential addition of $[\mathrm{IrCl}(\mathrm{cod})]_{2}$ (5 mol\% of Ir), (S,S)-QuinoxP* (6 mol\%), and $\mathrm{NaBArF}_{4}(10 \mathrm{~mol} \%)$ at $100{ }^{\circ} \mathrm{C}$ for $18 \mathrm{~h}$. Isolated yields are shown. ${ }^{b} 10 \mathrm{~mol} \%$ of $\mathrm{Ir}, 12 \mathrm{~mol} \%(S, S)$-QuinoxP*, and $20 \mathrm{~mol} \%$ of $\mathrm{NaBAr}_{4}{ }_{4}$ were used. ${ }^{c}(S)$-Difluorphos was used instead of $(S, S)$-QuinoxP*. ${ }^{d}$ Initial allylic substitution was performed at $60^{\circ} \mathrm{C}$.

Scheme 10. Synthesis of dihydrobenzofurans via Pd-catalyzed intermolecular allylic substitution and Ir-catalyzed asymmetric intramolecular hydroarylation ${ }^{a}$

\section{Conclusions}

In summary, we found that iridium/(S,S)-QuinoxP* complex catalyzed intramolecular hydroarylation of $\mathrm{m}$ cinnamyloxyphenyl ketones to give 3-substituted dihydrobenzofurans by 5-exo-cyclization in both high yields and enantioselectivity. A broad range of $m$-cinnamyloxyphenyl ketones were applicable to the present reaction. We also found that the presence of 4-methoxystyrene significantly improved the yield of the cyclized product within a shorter reaction time. Furthermore, in terms of synthetic utility, we developed the one-pot process to dihydrobenzofurans through Pd-catalyzed allylic substitution from readily available starting materials and Ir-catalyzed intramolecular hydroarylation in a highly enantioselective manner.

\section{Conflicts of interest}

There are no conflicts to declare.

\section{Acknowledgements}

This work was supported by JSPS KAKENHI Grant No. JP19H02721 and JP20J23499. K.S. thanks the JSPS for a research Fellowship for Young Scientists.

\section{Notes and references}

1 For reviews of asymmetric reactions involving $\mathrm{C}-\mathrm{H}$ activation, see: (a) L. Woźniak, J.-F. Tan, Q.-H. Nguyen, A. M. du Vigné, V. Smal, Y.-X. Cao and N. Cramer, Chem. Rev., 2020, 120, 1051610543; (b) D. F. Fernández, J. L. Mascarñas and F. López, Chem. Soc. Rev., 2020, 49, 7378-7405; (c) C. G. Newton, S.-G. Wang, C. C. Oliveira and N. Cramer, Chem. Rev., 2017, 117, 89088976; (d) C. Zheng and S.-L. You, RSC Adv., 2014, 4, 61736214; (e) R. Giri, B.-F. Shi, K. M. Engle, N. Maugel and J.-Q. Yu, Chem. Soc. Rev., 2009, 38, 3242-3272.

2 For selected examples of intramolecular hydroarylation via $\mathrm{C}$ H activation, see: (a) K. L. Tan, R. G. Bergman and J. A. Ellman, J. Am. Chem. Soc., 2001, 123, 2685-2686; (b) R. K. Thalji, K. A. Ahrendt, R. G. Bergman and J. A. Ellman, J. Am. Chem. Soc., 2001, 123, 9692-9693; (c) A. T. Normand, S. K. Yen, H. V. Huynh, T. S. Andy Hor and K. J. Cavell, Organometallics, 2008, 27, 3153-3160; (d) T. Shibata, S. Takayasu, S. Yuzawa and T. Otani, Org. Lett., 2012, 14, 5106-5109; (e) Z. Ding and N. Yoshikai, Angew. Chem., Int. Ed., 2013, 52, 8574-8578; (f) B. J. Fallon, E. Derat, M. Amatore, C. Aubert, F. Chemla, F. Ferreira, A. Perez-Luna and M. Petit, Org. Lett., 2016, 18, 2292-2295; (g) A. Carral-Menoyo, N. Sotomayor and E. Lete, J. Org. Chem., 2020, 85, 10261-10270; (h) T. A. Davis, T. K. Hyster and T. Rovis, Angew. Chem., Int. Ed., 2013, 52, 14181-14185; (i) Z. Guan, S. Chen, Y. Huang and H. Yao, Org. Lett., 2019, 21, 3959-3962; (j) P. A. Donets and N. Cramer, Angew. Chem., Int. Ed., 2015, 54, 633-637; (k) K. Ghosh, R. K. Rit, E. Ramesh and A. K. Sahoo, Angew. Chem., Int. Ed., 2016, 55, 7821-7825; (I) P. Kilaru, S. P. Acharya and P. A. Zhao, Chem. Commun., 2018, 54, 924-927; (m) D. F. Fernández, M. Gulías, J. L. Mascareñas and F. López, Angew. Chem., Int. Ed., 2017, 56, 9541-9545. 
For a recent review see: (n) A. Peneau, C. Guillou and L. Chabaud, Eur. J. Org. Chem. 2018, 5777-5794.

3 (a) N. Fujii, F. Kakiuchi, A. Yamada, N. Chatani and S. Murai, Chem. Lett., 1997, 425-426; (b) N. Fujii, F. Kakiuchi, A. Yamada, N. Chatani and S. Murai, Bull. Chem. Soc. Jpn., 1998, 71, 285298.

4 (a) R. K. Thalji, J. A. Ellman and R. G. Bergman, J. Am. Chem. Soc., 2004, 126, 7192-7193; (b) A. Watzke, R. M. Wilson, S. J. O'Malley, R. G. Bergman and J. A. Ellman, Synlett, 2007, 23832389; (c) A. S. Tsai, R. M. Wilson, H. Harada, R. G. Bergman and J. A. Ellman, Chem. Commun., 2009, 3910-3912; (d) D. A Colby, A. S. Tsai, R. G. Bergman and J. A. Ellman, Acc. Chem. Res., 2012, 45, 814-825.

5 B. Ye, P. A. Donets and N. Cramer, Angew. Chem., Int. Ed., 2014, 53, 507-511.

6 (a) T. Shibata, N. Ryu and H. Takano, Adv. Synth. Catal., 2015, 357, 1131-1135; (b) T. Shibata, H. Kurita, S. Onoda and K. S. Kanyiva, Asian J. Org. Chem., 2018, 7, 1411-1418.

7 (a) Z.-Y. Li, H. H. C. Lakmal, X. Qian, Z. Zhu, B. Donnadieu, S. J. McClain, X. Xu and X. Cui, J. Am. Chem. Soc., 2019, 141, 15730-15736; (b) G. Li, Q. Liu, L. Vasamsetty, W. Guo and J. Wang, Angew. Chem., Int. Ed., 2020, 59, 3475-3479.

8 During our preparation of the current manuscript, Cavallo, Rueping, and co-workers reported a similar work: V. S. Shinde, M. V. Mane, L. Cavallo and M. Rueping, Chem. Eur. J., 2020, 26, 8308-8313.

9 For examples of asymmetric exo-cyclization involving $\mathrm{C}-\mathrm{H}$ activation of azoles, see: (a) Y.-X. Wang, S.-L. Qi, Y.-X. Luan, X.W. Han, S. Wang, H. Chen and M. Ye, J. Am. Chem. Soc., 2018, 140, 5360-5364; (b) S.-J. Lou, Z. Mo, M. Nishiura and Z. Hou, J. Am. Chem. Soc., 2020, 142, 1200-1205; For selected examples of asymmetric cyclization involving $\mathrm{sp}^{3} \mathrm{C}-\mathrm{H}$ activation, see: (c) T. Ohmura, S. Kusaka, T. Torigoe and M. Suginome, Adv. Synth. Catal., 2019, 361, 4448-4453; (d) T. Torigoe, T. Ohmura and M. Suginome, Angew. Chem., Int. Ed., 2017, 56, 14272-14276; (e) Q. Li and Z.-X. Yu, Angew. Chem., Int. Ed., 2011, 50, 2144-2147.

10 K. Sakamoto and T. Nishimura, Adv. Synth. Catal., 2019, 361, 2124-2128.

11 For our recent reports on the Ir-catalyzed asymmetric reactions involving $\mathrm{C}-\mathrm{H}$ activation, see: (a) M. Hatano, Y. Ebe, T. Nishimura and H. Yorimitsu, J. Am. Chem. Soc., 2016, 138, 4010-4013; (b) D. Yamauchi, T. Nishimura and H. Yorimitsu, Chem. Commun., 2017, 53, 2760-2763; (c) Y. Ebe, M. Onoda, T. Nishimura and H. Yorimitsu, Angew. Chem., Int. Ed., 2017 56, 5607-5611; (d) M. Nagamoto, K. Sakamoto and T. Nishimura, Adv. Synth. Catal., 2018, 360, 791-795.

12 (a) Z. Chen, M. Pitchakuntla and Y. Jia, Nat. Prod. Rep., 2019, 36, 666-690; (b) A. Radadiya and A. Shah, Eur. J. Med. Chem., 2015, 97, 356-376.

13 H. Takaya, K. Mashima, K. Koyano, M. Yagi, H. Kumobayashi, T. Taketomi, S. Akutagawa and R. Noyori, J. Org. Chem., 1986, 51, 629-635.

14 T. Saito, T. Yokozawa, T. Ishizaki, T. Moroi, N. Sayo, T. Miura and H. Kumobayashi, Adv. Synth. Catal., 2001, 343, 264-267.

15 J.-P. Genet, T. Ayad and V. Ratovelomanana-Vidal, Chem. Rev. 2014, 114, 2824-2880.

16 R. Schmid, J. Foricher, M. Cereghetti and P. Schönholzer, Helv. Chim. Acta, 1991, 74, 370-389.

17 J. F. G. A. Jansen and B. L. Feringa, Tetrahedron: Asymmetry, 1990, 1, 719-720.

18 T. Imamoto, K. Sugita and K. Yoshida, J. Am. Chem. Soc., 2005, 127, 11934-11935.

19 W. You and M. K. Brown, J. Am. Chem. Soc., 2015, 137, 1457814581.

20 M. Hatano, T. Nishimura and H. Yorimitsu, Org. Lett., 2016, 18, 3674-3677.
21 The $H / D$ exchange of ortho- $\mathrm{C}-\mathrm{H}$ bonds of 4methoxyacetophenone was observed in the presence of $\mathbf{5 a -}$ $\boldsymbol{d}_{\mathbf{3}}$ under the similar reaction conditions using binap as a ligand. See. ref. 10.

22 E. M. Simmons and J. F. Hartwig, Angew. Chem., Int. Ed., 2012, 51, 3066-3072.

23 (a) M. Zhang and G. Huang, Dalton Trans., 2016, 45, 3552; (b) M. Zhang, L. Hu, Y. Lang, Y. Cao and G. Huang, J. Org. Chem., 2018, 83, 2937-2947.

24 (a) C. Goux, M. Massacret, P. Lhoste and D. Sinou, Organometallics, 1995, 14, 4585-4593; (b) A. lourtchenko and D. Sinou, J. Mol. Catal. A: Chem., 1997, 122, 91-93; (c) K. Takahashi, A. Miyake and G. Hata, Bull. Chem. Soc. Jpn., 1972, 45, 230-236; (d) D. R. Deardorff, R. G. Linde II, A. M. Martin and M. J. Shulman, J. Org. Chem., 1989, 54, 2759-2762; (e) E. Keinan and Z. Roth, J. Org. Chem., 1983, 48, 1769-1772; (f) E. Keinan, M. Sahai, Z. Roth, A. Nudelman and J. Herzig, J. Org. Chem., 1985, 50, 3558-3566.

25 C. Defieber, M. A. Ariger, P. Moriel and E. M. Carreira, Angew. Chem., Int. Ed., 2007, 46, 3139-3143.

26 (a) L. Nœsborg, K. S. Halskov, F. Tur, S. M. N. Mønsted and K. A. Jørgensen, Angew. Chem., Int. Ed., 2015, 54, 10193-10197, (b) S. Panda and J. M. Ready, J. Am. Chem. Soc., 2018, 140, 13242-13252. 